\title{
ANALISA KINERJA KEUANGAN PADA TRANSFORMASI PNPM MP MENJADI PROGRAM KOTA TANPA KUMUH DI KOTA BIMA
}

\section{Ecoplan}

Vol. 3 No. 1, April

2020, hlm 12-16

ISSN p: 2620-6102

e: $2615-5575$

\author{
Ida Nurillah ${ }^{1 *}$, Wulandari ${ }^{2}$, \\ 1) ${ }^{2}$ Sekolah Tinggi Ilmu Ekonomi Bima \\ *E-mail corresponding author: idanurillah.stiebima@gmail.com
}

\begin{abstract}
This research aims to describe the differences in UPK BKM Financial Performance before and after the transformation of PNPM MP into the KOTAKU Program in Bima City. UPK's financial performance is proxied using Loans at Risk (LAR), Portfolio at Risk (PAR), Return on Investment (ROI) and Cost Coverage Ratio $(\mathrm{CCr})$. The type of this research is descriptive analysis. The populationin in this research includes all UPK BKM in Bima City totaling 38 UPK BKM with a sample of 5 UPK BKM. The sampling technique uses purposive sampling. This technique is conducted by collecting data with documentation. Moreover, the data analysis technique used in this study is the analysis of the normality test and t-test hypothesis test. The results of the research show that: (1) There are differences in the Loans at Risk (LAR) before and after the transformation of PNPM MP into the KOTAKU Program. (2) There are differences in the Portfolio at Risk (PAR) before and after the transformation of PNPM MP into the KOTAKU Program. (3) There are differences in Return on Investment (ROI) before and after the transformation of PNPM MP into the KOTAKU Program. (4) There are differences in Cost Coverage (CCr) before and after the transformation of PNPM $M P$ into the KOTAKU Program.
\end{abstract}

Keywords: $L A R, P A R, R O I, C C r$

\section{THE ANALYSIS OF FINANCIAL PERFORMANCE IN TRANSFOR- MATION OF PNPM MP TO BECOME KOTA TANPA KUMUH AT BIMA CITY}

\begin{abstract}
Abstrak-Penelitian ini bertujuan untuk memaparkan perbedaan Kinerja Keuangan UPK BKM sebelum dan sesudah transformasi program PNPM Mandiri Perkotaan menjadi Program KOTAKU di Kota Bima. Kinerja Keuangan UPK diproksikan menggunakan Loan at Risk (LAR), Portofolio at Risk (PAR), Return on Investment (ROI) dan Cost Coverage Ratio (CCr). Jenis penelitian ini yaitu analisis deskriptif. Populasi mencakup seluruh UPK BKM di Kota Bima yang berjumlah 38 UPK BKM dengan sampel berjumlah 5 UPK BKM. Teknik pengambilan sampel menggunakan teknik purposive sampling, teknik pengumpulan data dengan dokumentasi dan teknik analisis data yang digunakan dalam penelitian ini adalah analisis uji normalitas dan uji hipotesis t-test. Hasil penelitian yang telah dilakukan menunjukkan bahwa: (1) Terdapat perbedaan pada Loans at Risk (LAR) sebelum dan sesudah transformasi PNPM Mandiri Perkotaan menjadi Program KOTAKU. (2) Terdapat perbedaan pada Portfolio at Risk (PAR) sebelum dan sesudah transformasi PNPM Mandiri Perkotaan menjadi Program KOTAKU. (3) Terdapat perbedaan pada Return on Investment (ROI) sebelum dan sesudah transformasi PNPM Mandiri Perkotaan menjadi Program KOTAKU. (4) Terdapat perbedaan pada Cost Coverage (CCr) sebelum dan sesudah transformasi PNPM Mandiri Perkotaan menjadi Program KOTAKU.
\end{abstract}

Kata kunci : $L A R, P A R, R O I, C C r$.
Jl. H. Hasan Basry No.29, Pangeran, Banjarmasin Utara, Kota Banjarmasin, Kalimantan Selatan E-mail:

ecoplan@ulm.ac.id 


\section{PENDAHULUAN}

Program Nasional Pemberdayaan Masyarakat Mandiri Perkotaan (PNPM MP) yaitu program pemerintah yang substansinya adalah penanggulangan kemiskinan dengan konsep pemberdayaan masyarakat melalui implentasi kegiatan tridaya, yaitu kegiatan ekonomi, kegiatan sosial dan kegitan infrastruktur pada wilayah perkotaan

PNPM MP berjalan mulai tahun 2007 sampai dengan tahun 2014, dalam pelaksanaan kegiatannya mendorong terbangunnya wadah sinergi penanggulangan kemiskinan di masyarakat yaitu Lembaga Keswadayaan Masyarakat (BKM). Pemerintah menyalurkan dana PNPM melalui kelurahan dan setiap kelurahan penerima bantuan harus memiliki Badan Keswadayaan Masyarakat (BKM) yang akan mengkoordinasi bantuan dana kepada Kelompok Swadaya Masyarakat (KSM) yang berada di wilayahnya (PNPM, 2012).

BKM itu sendiri merupakan organisasi non Profit, sebagai lembaga penyalur dana PNPM MP memiliki perangkat yang juga mengacu pada tridaya, yaitu Unit Pengelola Sosial (UPS) sebagai pengelola kegiatan sosial, Unit Pengelola Lingkungan (UPL) sebagai pengelola kegiatan lingkungan dan Unit Pengelola Keuangan (UPK) sebagai pengelola kegiatan ekonomi dalam hal ini pinjaman bergulir.

Selanjutnya dengan adanya surat BAST Nomor 100/1694/SJ dan Nomor 01/BA/M-DPDTT/ IV/2015 Kemendagri dan Kemendes PDTT dana bantuan program PNPM Mandiri Perkotaan dihentikan, yang kemudian bertransformasi menjadi program Kota Tanpa Kumuh (KOTAKU) yang berpijak pada UU No.1 tahun 2011 tentang perumahan dan kawasan permukiman dimana alokasi dana hanya untuk kegiatan Infrastruktur. Dengan demikian alokasi kegiatan ekonomi pada BKM atau tambahan modal untuk pinjaman bergulir pada UPK BKM sudah tidak ada.

Kota Bima merupakan salah satu Kota yang diintervensi program PNPM MP dan juga Program KOTAKU yang dalam pelaksanaannya telah terbangun 38 BKM. Selama pelaksanaan Program PNPM MP, penambahan modal pada UPK tetap teralokasi dalam BLM pada tiap tahun, alokasi tersebut tentunya dengan pertimbangan hasil penilaian ki-nerja keuangan UPK yang sangat baik atau sehat, dengan begitu memberi ruang semakin berkembangnya lembaga UPK. Namun pasca transformasi program dalam 4 tahun terakhir kinerja pengelolaan keuangan UPK BKM Kota Bima menunjukkan penurunan atau tidak sehat, UPK Hanya mengembangkan dari modal yang ada, hal tersebut sangat berpengaruh pada besarnya pendapatan UPK yang tidak meningkat sehingga mempengaruhi motivasi penagihan. Kurang aktifnya UPK menimbulkan kemacetan pengemba-lian KSM sehingga nilai tunggakan semakin meningkat. Sebagaimana data pada UPK BKM di 5 Kelurahan sampel, total dana alokasi kegiatan ekonomi untuk tambahan modal pinjaman bergulir dari Program
PNPM MP yang sudah digelontorkan dari tahun 2011 sebesar Rp.165.500.000, dan pada tahun 2018 nilai pinjaman menunggak sebesar Rp.121,250,000,- dari 42 KSM menunggak di atas 3 bulan.

Sementara itu kinerja keuangan UPK sangatlah penting dijaga kestabilannya sebagaimana UPK bagi BKM diharapkan untuk bisa tetap menghasilkan laba dan berjalan untuk menunjang misi utama BKM yaitu menanggulangi kemiskinan melalui kegiatan pinjaman bergulir yang dapat meningkatkan pendapatan masyarakat miskin. Bagi UPK sendiri Kinerja keuangan digunakan untuk mengetahui beberapa kelemahan yang menjadi kekurangan UPK, untuk memprediksi potensi yang mungkin akan dilakukan di masa yang akan datang dan juga sebagai dasar pengambilan keputusan.

Untuk mengukur kinerja keuangan UPK dapat dilihat dengan menggunakan rasio-rasio keuangan, dan telah ditentukan oleh Kementrian Pekerjaan Umum dalam Petunjuk Teknis Pinjaman Bergulir (2012), meliputi pinjaman yang tertunggak (Portfolio at Risk/PAR), peminjam yang menunggak (Loans at Risk/LAR), Pencapaian Laba (Return on Investment /ROI) dan Efisiensi biaya (Cost Coveragel $\mathrm{CCr}$ ). Analisis rasio sebagai sumber informasi keuangan, akan bermanfaat apabila angka-angka rasio tersebut di-bandingkan dari tahun ketahun sehingga bisa dideskripsikan kinerja keuangan UPK BKM pada tahun sebelum dan sesudah transformasi program PNPM MP menjadi program KOTAKU.

Berdasarkan latar belakang tersebut maka peneliti bertujuan untuk meneliti Analisa kinerja keuangan Unit Pengelola Keuangan (UPK) pada Badan Keswadyaan Masyarakat (BKM) Sebelum dan Sesudah Transformasi Program Pemberdayaan Masyarakat Mandiri Perkotaan (PNPM) menjadi Program Kota Tanpa Kumuh (KOTAKU) di Kota Bima".

\section{METODE PENELITIAN}

\section{Jenis Penelitian}

Penelitian ini merupakan jenis penelitian analisis deskriptif, Menurut (Sugiyono, 2017:2) "Analisis deskriptif adalah statistik yang digunakan untuk menganalisis data dengan cara mendeskripsikan atau menggambarkan data yang telah terkumpul sebagaimana adanya tanpa bermaksud membuat kesimpulan yang berlaku untuk umum atau generalisasi.”. Dalam hal ini mendiskripsikan kinerja keuangan UPK BKM Sebelum dan sesudah transformasi program PNPM MP menjadi Program Kota Tanpa Kumuh (KOTAKU) di Kota Bima sampel 5 kelurahan.

\section{Instrumen dan Pengukuran Indikator}

Instrument yang digunakan adalah data kuantitatif berupa daftar tabel indikator kinerja keuangan yang terdiri dari LAR, PAR, ROI, $\mathrm{CCr}$ dari tahun 2011 - 2018, untuk menganalisa kinerja keuangan. Teknik pengumpulan data dalam penelitian ini adalah metode dokumentasi, berdasarkan jenis data 
yang digunakan yaitu data sekunder yang diperoleh dari dokumentasi laporan keuangan akhir tahun di 5 UPK BKM sampel (UPK BKM Bina Mandiri Kelurahan Panggi, UPK BKM Bangkit Kelurahan Matakando, UPK BKM Ompu Lewi Kelurahan Lewirato, UPK BKM Manggemaci Kelurahan manggemaci, UPK BKM Doto To'i Kelurahan Mande ) tahun 2011-2018, berupa: Neraca, Laporan Laba rugi, kolektibilitas, form dana bergulir.

Pengukuran kinerja (Anggraini dan Puranto, 2010: 180), adalah suatu metode atau alat yang digunakan untuk mencatat atau menilai pencapaian pelaksanaan ke-giatan berdasarkan tujuan, sasaran, dan strategi sehingga dapat diketahui kemajuan organisasi serta meningkatkan kualitas pengambilan keputusan dan akuntabilitas. Pengukuran kinerja keuangan setiap organisasi ataupun perusahaan berbeda-beda tergantung pada lingkup yang dijalankannya. Begitu juga pada sektor lembaga atau badan yang menjalankan usahanya yaitu menyalurkan dana bantuan dari peme-rintah kepada masyarakat yang membutuhkan dan khususnya UPK dalam mengelola pinjaman bergulir.

Indikator-indikator penilaian kinerja keuangan UPK BKM tersebut, didapatkan dengan rumus sebagai berikut :

\section{Loans at Risk (LAR)}

Loan At Risk (LAR) merupakan indikator yang menunjukkan berapa persen peminjam yang menunggak, Angka ini diperoleh dari hasil membandingkan antara berapa KSM peminjam yang menunggak lebih dari tiga bulan dengan seluruh KSM peminjam yang masih memiliki saldo pinjaman, Dikatakan UPK BKM dalam kondisi sehat apabila PAR kurang dari 10\%. Loan at risk (LAR) dapat dirumuskan dengan:

Rumus LAR :

$$
\text { LAR }=\frac{\text { Jumlah KSM menunggak } \geq 3 \text { bulan }}{\text { Jumlah KSM peminjam }} \times 100 \%
$$

\section{Portfolio at Risk (PAR)}

Portofolio At Risk (PAR) adalah indikator yang menunjukkan berapa persen pinjaman yang tertunggak. Angka ini diperoleh dari hasil membandingkan antara jumlah pinjaman yang tertunggak lebih dari tiga bulan dengan total realisasi saldo pinjaman di UPK. Portofolio At Risk (PAR) menunjukan jumlah Kelompok Swa-daya Masyarakat (KSM) yang beresiko hilang atau menunggak lebih dari tiga bu-lan. Dikatakan UPK BKM dalam kondisi sehat apabila PAR kurang dari 10\%.

Rumus PAR :

$$
\text { PAR }=\frac{\text { Pinjaman tertunggak } \geq 3 \text { bulan }}{\text { Realisasi saldo pinjaman }} \times 100 \%
$$

\section{Return on Investment (ROI)}

ROI adalah kemampuan UPK untuk menghasilkan laba dari modal yang digunakan untuk pinjaman bergulir.Angka ini diperoleh dari hasil membandingkan antara laba yang diperoleh UPK dengan modal yang digunakan untuk pinjaman bergulir. Dikatakan sehat apabila UPK BKM dapat memperoleh minimal $10 \%$

Rumus ROI :

$$
R O I=\frac{\text { Laba bersih }}{\text { Modal Investasi }} \times 100 \%
$$

\section{Cost Coverage (CCr)}

CCR adalah kemampuan UPK untuk menutup biaya dari pendapatan yang diperolehnya. Angka ini diperoleh dari hasil membandingkan antara seluruh pendapatan yang diperoleh UPK dengan seluruh biaya yang dikeluarkan UPK. Modul Khusus Pinjaman Bergulir (2012:37). CCR mengukur berapa besar rasio pendapatan di-bandingkan biaya.Berapa pendapatan yang meng-cover biaya. Dikatakan berkinerja sehat apabila lebih besar dari $125 \%$.

Rumus $\mathrm{CCr}$ :

$$
\mathrm{CCr}=\frac{\text { Total pendapatan tunai UPK }}{\text { Total biaya tunai UPK }} \times 100 \%
$$

\section{Teknik Analisis Data}

Teknik analisis data pada penelitian ini dengan uji prasyarat menggunakan uji normalitas, yang bertujuan untuk memperlihatkan data sampel dari populasi berdistribusi normal (Gunawan, 2015: 67).

Tabel 1. Hasil Pengujian Normalitas data

\begin{tabular}{ccc}
\hline Variabel & Sig. & Kesimpulan \\
\hline LAR & 0,993 & Normal \\
PAR & 0,53 & Normal \\
ROI & 0,510 & Normal \\
CCr & 0,956 & Normal \\
\hline
\end{tabular}

Sumber: Hasil Olah Data

Dalam hal ini metode uji menggunakan uji normallitas kolmogorov smirnov untuk menghasilkan performa yang baik untuk ukuran data 20-1000. Serta uji Uji paired sample t-test untuk membandingkan perbedaan atau kesamaan rata-rata dua kelompok sampel data yang berkaitan/berpasangan (Yamin dan Kurniawan,

Tabel 2. Ringkasan Uji Hipotesis

\begin{tabular}{llll}
\hline \multirow{2}{*}{ Variabel } & \multicolumn{2}{c}{ Uji T } & \\
\cline { 2 - 3 } & Mean & Sig. & $\begin{array}{c}\text { Keputusan } \\
\text { Penelitian }\end{array}$ \\
LAR & 174.000 & 0,020 & H1 didukung \\
PAR & 216.400 & 0,010 & H2 didukung \\
ROI & 22.400 & 0,014 & H3 didukung \\
CCr & 365.600 & 0,020 & H4 didukung \\
\hline
\end{tabular}

Sumber: Hasil Olah Data 
2014: 56). Adapun dasar pengambilan keputusannya adalah melihat perbandingan angka probabilitas dengan aturan:

Sig. (2-tailed) $>\alpha$, dimana $\alpha=0,05>\mathrm{H} 0$ didukung.

Sig. (2-tailed) $<\alpha$, dimana $\alpha=0,05<\mathrm{H} 0$ tidak didukung.

\section{HASIL DAN PEMBAHASAN}

\section{Hasil Penelitian}

\section{Uji Normalitas Kolmogorov Smirnov}

Dari hasil uji normalitas, menghasilkan Tabel 1, nilai Sig. lebih besar dari 0,05. Berdasarkan kriteria uji normalitas yang disyaratkan harus lebih besar dari 5\%, maka disimpulkan bahwa data penelitian telah berdistribusi normal.

\section{Uji Hipotesis}

\section{Pembahasan}

Berdasarkan uji paired sample t-test diperoleh nilai signifikansi untuk variabel LAR sebesar 0,020. Besarnya nilai signifikansi lebih kecil dari nilai signifikansi yang ditetapkan sebesar 0,05. Hal ini menunjukkan bahwa terdapat perbedaan pada aspek Loans at Risk (LAR) sebelum dan sesudah transformasi program PNPM Mandiri Perkotaan menjadi Program Kota Tanpa Kumuh di Kota Bima.

Selanjutnya pada indikator PAR berdasarkan uji paired sample t-test diperoleh nilai signifikansi untuk variabel PAR sebesar 0,01. Be-sarnya nilai signifikansi lebih besar dari nilai signifikansi yang ditetapkan sebesar 0,05. Hal ini menunjukkan terdapat perbedaan pada aspek Portfolio at Risk (PAR) sebelum dan sesudah transformasi program PNPM Mandiri Perkotaan menjadi Program Kota Tanpa Kumuh di Kota Bima.

Pada indikator ROI berdasarkan uji paired sample t-test diperoleh nilai signifikansi untuk variabel ROI sebesar 0,014. Besarnya nilai signifikansi lebih kecil dari nilai signifikansi yang ditetapkan sebesar 0,05. Hal ini menunjukkan bahwa terdapat perbedaan pada aspek Return on Investment (ROI) sebelum dan sesudah transformasi program PNPM Mandiri Perkotaan menjadi Program Kota Tanpa Kumuh di Kota Bima, dengan demikian dapat dinyatakan bahwa terdapat perbedaan sebelum dan sesudah transformasi program PNPM Mandiri Perkotaan menjadi Program Kota Tanpa Kumuh di Kota Bima terhadap aspek ROI.

Hampir sama dengan indikator lainnya, pada indikator $\mathrm{CCr}$ berdasarkan uji paired sample t-test diperoleh nilai Signifikansi untuk variabel $\mathrm{CCr}$ sebesar 0,020. Besarnya nilai signifikansi lebih kecil dari nilai signifikansi yang ditetapkan sebesar 0,05 . Hal ini menunjukkan bahwa adanya perbedaan Cost Coverage (CCr) sebelum dan sesudah transformasi program PNPM Mandiri Perkotaan menjadi Program Kota Tanpa Kumuh di Kota Bima.

Hasil olah data menunjukkan adanya perbedaaan kinerja keuangan UPK BKM Kota Bima sebelum dan sesudah transformasi program PNPM
MP menjadi Program KOTAKU pada semua indikator LAR,PAR,ROI,CCr. Kinerja keuangan pada 4 tahun sebelum transformasi program rata-rata memuaskan atau sehat dimana tingkat kesadaran masyarakat dalam mentaati aturan program yang dijalankan oleh UPK masih tinggi. Hal tersebut menunjang kinerja LAR, PAR menjadi sangat baik karena minimnya KSM peminjam menunggak $\geq 3$ bulan. Indikator ROI dan $\mathrm{CCr}$ pun menjadi sangat baik dimana UPK teralokasi rutin penambahan modal tiap tahunnya dari program PNPM MP. Pengembangan modal dan tambahan modal dari pemupukkan modal memberi dampak meningkatnya pendapatan UPK, sehingga UPK mampu menutupi biaya operasional, insentif UPK yang memotivasi penagihan serta pembiayaan audit lembaga tahunan.

Namun setelah transformasi menjadi Program KOTAKU, beberapa UPK BKM di Kota Bima masih bisa mempertahankan kinerja keuangan yang sehat dengan pengembangan modal yang ada di tahun 2015. Kemudian pada tahun berikutnya sampai dengan tahun 2018, kinerja keuangan UPK BKM di Kota Bima secara keseluruhan tidak sehat disebabkan oleh faktor internal seperti pelaksanaan pemilihan ulang BKM yang juga mengganti pengurus UPK, proses transfer dokumen maupun aset dari UPK memakan waktu dan membutuhkan adaptasi pada UPK baru, sehingga penagihan menjadi kurang maksimal. Selain itu juga masih lemah aturan terkait sanksi pada anggota KSM peminjam yang menunggak, dan berpengaruh buruk pada motivasi anggota KSM yang sebelumnya lancar.

Faktor eksternalnya adalah ketiadaan alokasi dana kegiatan Ekonomi untuk modal pinjaman bergulir UPK setelah transformasi menjadi program KOTAKU, hal tersebut memberi efek kelesuan dalam aktifitas UPK, dimana KSM peminjam dan saldo pinjaman yang menunggak $\geq 3$ bulan semakin meningkat, menjadikan saldo UPK minim, dan UPK mengalami keterbatasan memenuhi usulan pinjaman KSM, perguliran dana menjadi tidak berjalan, pendapatan UPK mengalami penurunan karena angsuran dan jasa pinjaman tidak berjalan. faktor lainnya juga dikarenakan pada masa intervensi Program KOTAKU, perhatian BKM pada UPK dan kegiatan pinjaman bergulir kurang maksimal, dikarenakan BKM fokus pada kegiatan infrastruktur. yang seharusnya pada masa transformasi program KOTAKU, peranan BKM terhadap kinerja UPK sangatlah dibutuhkan, manakala era program KOTAKU mengusung konsep kolaborasi dalam penanganan kumuh. selain permasalah infrastruktur, juga mendorong adanya kolaborasi dari berbagai pihak untuk mendukung kegiatan UPK, sebab salah satu penyumbang kumuh adalah masyarakat berpenghasilan rendah, dengan melalui adanya kegiatan dana bergulir pada UPK dapat membantu masyarakat dalam peningkatan kesejateraan masyarakat.

Penelitian ini relevan dengan penelitian Fraternesi dan Yusmaniarti dengan Judul "Analisis Kinerja Pinjaman bergulir pasca alih kelola program 
PNPM ke Program Kotaku di Provini Bengkulu"(Jurnal), yang memaparkan analisis 4 Indikator (LAR, PAR, ROI, CCr) pada Unit Pengelola Keuangan PNPM Mandiri Perkotaan Provinsi Bengkulu dalam hal kegiatan dana pinjaman bergulir dengan sampel 1 tahun sebelum (tahun 2013) dan 1 tahun sesudah (tahun 2014), yaitu indikator LAR dan PAR pada status penundaan (tidak sehat) sedangkan pada indikator ROI status minimum (cukup sehat), dimana penyebab rendahnya tingkat pengembalian dana pinjaman bergulir dianalisis dari level KSM, yaitu pengaruh Kelompok Lain Yang Menunggak tidak ada hukuman, usaha Kelompok Swadaya Masyarakat (KSM) Macet. level UPK : Ketua UPK tidak melakukan penagihan, dibentuk panitia penagihan tetapi tidak aktif dan kurang kepercayaan kepada ketua KSM. Pada level BKM, penyebabnya adalah Badan Keswadayaan Masyarakat (BKM) tidak aktif, Badan Keswadayaan Masyarakat (BKM) tidak memberikan pengawasan terhadap UPK, Badan Keswadayaan Masyarakat (BKM) ikut pinjaman tetapi macet. Pada level elit kelurahan: penyalah gunaan dana pinjaman oleh Elit Kelurahan, Perangkat Lurah ada yang meminjam tetapi macet. dan pada level konsultan : Waktu kunjungan Uji petik Lapangan kurang, Fasilitator ikut bermain/ berkerjasama menggunakan uang UPK.

Hasil penelitian ini juga sejalan dengan penelitian Muhammad Idris "Analisis Kinerja Keuangan Unit Pengelola Keuangan pada Badan Keswadayaan Masyarakat sebelum dan sesudah Pemberhentian Dana PNPM Mandiri Perkotaan di Kabupaten Bantul'(2017), yaitu membandingkan kinerja keuangan UPK BKM 1 tahun sebelum dan sesudah pemberhentian dana PNPM MP tabun 2014 dan 2015, dengan hasil pemberhentian dana PNPM berpengaruh atau terdapat perbedaan pada indikator ROI sedangkan indikator lainnya LAR, PAR dan CCr tidak berbeda atu tidak berpengaruh. Tidak terdapatnya perbedaan disebabkan karena kinerja keuangan dari 3 indikator tidak mengalami kenaikan maupun penurunan.

Perbandingan penelitian ini, dengan penelitian sebelumnya, meneliti objek yang sama yaitu kinerja keuangan UPK BKM, hanya saja dalam penelitian ini mengambil sampel 8 tahun, yang dirinci dengan 4 tahun sebelum dan sesudah trasnformasi PNPM MP menjadi Program KOTAKU. Dengan melakukan perbandingan kinerja keuangan UPK dari tahun ke tahun, sampai pada kondisi terkini yaitu tahun 2018, dapat disimpulkan kinerja keuangan UPK, yang kemudian bisa menjadi acuan baik bagi UPK, BKM, untuk pengembangan program serta kebijakan pemerintah sehingga menyadari adanya potensi UPK sebagai lembaga keuangan di tingkat kelurahan yang perlu dibina dan dikembangkan.

\section{KESIMPULAN}

Berdasarkan hasil penelitian pembahasan di atas maka dapat disimpulkan: (1) Terdapat perbedaan kinerja keuangan pada Loans at Risk (LAR) sebelum dan sesudah transformasi program PNPM MP menjadi Program KOTAKU di Kota Bima, dimana sebelum transformasi pencapaian pada aspek LAR sebagian besar UPK BKM dalam kategori me-muaskan (sehat) dan setelah transformasi dalam kondisi penundaan (tidak sehat). (2) Terdapat perbedaan pada Portfolio at Risk (PAR) sebelum dan sesudah transformasi program PNPM MP menjadi Program KOTAKU di Kota Bima, dimana sebelum transformasi pencapaian pada aspek PAR sebagian besar UPK BKM dalam kategori memuaskan (sehat) dan setelah transformasi dalam kondisi penundaan (tidak sehat). (3) Terdapat perbedaan pada Return on Investment (ROI) sebelum dan sesudah transformasi program PNPM MP menjadi Program KOTAKU di Kota Bima, dimana sebelum transformasi pencapaian pada aspek ROI UPK BKM dalam kategori memuaskan dan minimal dan setelah transformasi dalam kondisi penundaan (tidak sehat). (4) Terdapat perbedaan pada Cost Coverage $(\mathrm{CCr})$ sebelum dan sesudah transformasi program PNPM MP menjadi Program KOTAKU di Kota Bima, dimana sebelum transformasi pen-capaian pada aspek $\mathrm{CCr}$ sebagian besar UPK BKM dalam kategori memuaskan (sehat) dan setelah transformasi dalam kondisi penundaan (tidak sehat)

Dari kesimpulan di atas maka dapat diberikan saran untuk menjadi bahan perbaikan kinerja keuangan UPK BKM Kota Bima sebagai berikut: (1) Meningkatkan kepedulian Badan Keswadayaan Masyarakat (BKM) terhadap UPK dan permasalah kegiatan dana bergulir. (2) Penguatan dan revitalisasi pengurus UPK. (3) Membentuk tim penanganan dana bergulir yang melibatkan berbagai unsur, yang akan melakukan identifikasi anggota KSM macet, serta melakukan kunjungan penagihan kepada peminjam. (4) Melakukan Rescheduling pada KSM dengan memperpanjang jangka waktu angsuran serta Reconditioning, artinya memberikan penundaaan pembayaran jasa pinjaman atau membebaskan jasa pinjaman KSM. (5) Mencairkan dana yang mengendap di bank pada KSM dengan proses verifikasi yang benar serta penerapan konsep panca sutra yakni pertemuan rutin, menabung, pencatatan, peminjmaan dan pengembalian. (6) Apabila anggota KSM mengalami kematian, kebakaran dan macet total, maka bisa dilakukan penutupan tunggakan pinjaman dengan biaya cadangan resiko yang telah dianggarkan. (7) Sistem tanggung renteng dapat terus dilanjutkan pada program Kotaku sebagai pengganti Program PNPM MP yang sudah ditutup, dengan catatan benar-benar diterapkan aturan dalam kelompok. (8) BKM membangun kolaborasi dengan pihak lain dalam upaya penambahan modal UPK.

\section{DAFTAR PUSTAKA}

Anggraini, Y. dan Hendra, P. (2010). “Anggaran Berbasis Kinerja;Penyusunan APBD Secara Komprehensif'. Yogyakarta: STIM YKPN.

Direktorat Jenderal Cipta Karya - Kementrian Pekerjaan Umum. (2012). "Petunjuk Teknis Pinjaman Bergulir"”. 